\title{
PENYULUHAN DAN SURVEI TENTANG PENDAPAT MASYARAKAT TENTANG COVID SETELAH 5 BULAN DI DESA SUKAMAKMUR, KECAMATAN JONGGOL, JAWA BARAT
}

\section{COUNTRY AND SURVEY ON PUBLIC OPINION ON COVID AFTER 5 MONTHS IN SUKAMAKMUR VILLAGE, JONGGOL KECAMATAN, JAWA BARAT}

\author{
Feda Makkiyah $^{1)}$, Yuni Setyaningsih ${ }^{2)}$ \\ ${ }^{1,2}$ Fakultas Kedokteran, Universitas Pembangunan Nasional Veteran Jakarta \\ Email: fedaanisah@upnvj.ac.id
}

\begin{abstract}
Abstrak: Pandemi COVID-19 telah menimbulkan morditas dan mortalitas di Indonesia. Setelah 5 bulan penyebaran, COVID-19 belum terlihat mereda. Pengabdian ini berusaha meningkatkan aspek promotif dengan memberikan edukasi kepada masyarakat pedesaan di Desa Sukamakmur, Kabupaten Bogor, Jawa Barat. Metode pengabdian dilakukan di awal bulan Agustus 2020 dengan memberikan penyuluhan dan memberikan kuesioner untuk mengetahui tingkat pengetahuan dan perilaku masyarakat tentang kebiasaan hidup sehat. Hasil pengabdian kepada masyarakat tentang penyuluhan covid setelah 5 bulan penyebaran COVID-19 di Indonesia memberikan petunjuk bahwa pengetahuan masyarakat masih rendah tentang covid dan kebiasaan masyarakat di desa Sukamakmur tentang perilaku pencegahan COVID-19 sudah cukup baik.
\end{abstract}

Kata Kunci: Pengabdian, Pengetahuan, Masyarakat, COVID, 5 Bulan.

Abstract: COVID-19 pandemic has caused morbidity and mortality in Indonesia. After 5 months pandemic, the COVID-19 progress dramatically. This health community service was an effort to strengthen promotive aspects with educating community villagers in Sukamakmur village, Bogor district, east java. This meeting was held in begining of August 2020. Small groups discussion and quesionnaires data collecting were performed in that meeting. This techniques were delivered to gain the knowledge of the community people and to acknowledge their healthy behaviour. After 5 months pandemic, the level of knowledge of Sukamakmur villagers about COVID-19 considered low-moderate level. However, regarding the healthy behaviours such as face-mask application and wash hands were adopted sufficiently by this villagers.

Keywords: Community, Health Service, Knowledge, Villagers, COVID, 5 Months.

\section{PENDAHULUAN}

Sampai tanggal 24 November 2020, pemerintah Indonesia sudah melaporkan 506.302 penderita yang positif terkonfirmasi dengan COVID-19. Angka kematian dilaporkan mencapai 16.111 dan 425.313 penderita dilaporkan telah sembuh dari penyakit ini.

COVID-19 adalah penyakit dengan penyebab virus Corona yang menyebar lewat pernafasan. Virus ini dikonfirmasi di Indonesia mulai Maret 2020. Virus ini 


\section{INTEGRITAS : Jurnal Pengabdian}

Vol 4, No 2, Desember 2020

ISSN $2580-7978$ (cetak) ISSN 2615 - 0794 (online)

menyebabkan pandemi di seluruh negara dan sampai saat ini belum bisa dipastikan kapan akan berakhir.

Indonesia adalah negara keempat dengan populasi terbesar di dunia dan diprediksi menderita lebih besar dan lebih lama dibandingkan dengan negara dengan populasi yang lebih rendah. Pengabdian masyarakat ini merupakan aspek edukasi yang merupakan kegiatan promotif untuk mencegah rantai penyebaran dari virus Corona ini. Peningkatan pengetahuan masyarakat untuk berprilaku sehat akan menurunkan penyebaran virus ini yang sudah menimbulkan mortalitas di masyarakat.

Desa Sukamakmur, adalah Desa di Kabupaten Bogor, yang jaraknya sekitar $60 \mathrm{~km}$ dari Jakarta Selatan. Meskipun jaraknya cukup dekat dengan perbatasan kota Jakarta, akan tetapi masyarakatnya masih hidup dalam taraf sosio-ekonomi menengah ke bawah. Kegiatan penyuluhan pada masyarakat ini akan membantu meningkatkan kesadaran akan perilaku hidup bersih dan sehat.

\section{METODE}

Pengabdian ini dilakukan satu hari tanggal 4 Agustus 2020. Pengabdian dilakukan di balai desa, dengan menerapkan protokol kesehatan, yaitu memakai masker, menjaga jarak dan mencuci tangan. Kegiatan pertama dilakukan dengan perkenalan dan dilanjutkan dengan penyuluhan yang diisi dengan materi tentang COVID-19 disertai dengan demonstrasi perilaku menjaga kesehatan di masa pandemi. Para responden yang kumpul diberikan kuesioner dan pertanyaan yang akan menentukan tingkat pengetahuan setelah 5 bulan pandemi COVID-19.

\section{HASIL DAN PEMBAHASAN}

Pengabdian berupa penyuluhan tentang COVID-19 dihadiri oleh 42 orang, dengan perempuan sebanyak 38 orang dan pria 4 orang. Tingkat pendidikan responden tersebut kebanyakan adalah tingkat pendidikan rendah yaitu sekolah dasar sebanyak 30 orang. Responden tersebut kebanyakan dengan pekerjaan ibu rumah tangga 31 orang (Tabel 1). 


\section{INTEGRITAS : Jurnal Pengabdian}

Vol 4, No 2, Desember 2020

ISSN $2580-7978$ (cetak) ISSN 2615 - 0794 (online)

Tabel 1 Karakteristik Responden Penyuluhan kepada Masyarakat

\begin{tabular}{|c|c|}
\hline Karakteristik Masyarakat & $\begin{array}{c}\text { Jumlah }(\mathrm{n}=42 \\
\text { orang) }\end{array}$ \\
\hline Jenis Kelamin Perempuan & 38 \\
\hline Laki-laki & 4 \\
\hline Tingkat Pendidikan SD & 30 \\
\hline SMP & 6 \\
\hline SMA & 6 \\
\hline Pekerjaan & 31 \\
\hline Kader & 5 \\
\hline+2 & 6 \\
\hline
\end{tabular}

Mengenai tingkat pengetahuan tentang COVID-19, setengah dari responden (28 orang) dengan tingkat pengetahuan sedang-rendah. Pengetahuan baik hanya didapatkan pada 17 orang (Tabel 2).

Tabel 2. Tingkat Pengetahuan Persepsi tentang COVID-19

\begin{tabular}{|c|c|}
\hline Tingkat Pengetahuan & $\begin{array}{c}\text { Jumlah responden (42 } \\
\text { orang) }\end{array}$ \\
\hline Baik & 17 \\
\hline Sedang & 14 \\
\hline Rendah & 12 \\
\hline
\end{tabular}

Kebiasaan hidup sehat selama pandemi COVID-19 telah dijalani dengan baik pada masyarakat Desa Sukamakmur, Kecamatan Jonggol, Jawa Barat. Kebiasaan mencuci tangan sesampai di rumah dilakukan selalu oleh 32 responden, akan tetapi mencuci tangan lebih dari 20 detik, dijawab dengan kadang-kadang pada 21 responden (Tabel 3).

Kebiasaan hidup sehat yang sudah dijalani dengan baik lainnya adalah selalu mencuci tangan dengan sabun (36 orang), selalu mencuci tangan pada air mengalir (32 orang), selalu memakai masker jika keluar rumah (31 orang), anak saya selalu memakai masker (30 orang).

Kebiasaan yang belum dipatuhi dengan baik adalah selalu menjaga jarak (13 orang), selalu membatasi ke luar rumah (16 orang), menyenyuh wajah (1 orang), 


\section{INTEGRITAS : Jurnal Pengabdian}

Vol 4, No 2, Desember 2020

ISSN $2580-7978$ (cetak) ISSN 2615 - 0794 (online)

selalu pakai face shield (3 orang). Pergi ke pasar tradisional masih dijawab kadang (22 orang) dan kadang pergi ke hajatan (11 orang).

Tabel 3. Gambaran Pertanyaan tentang Kebiasaan Hidup Sehat Selama Pandemi COVID-19

\begin{tabular}{|c|c|c|c|c|}
\hline & SELALU & KADANG & TIDAK & $\begin{array}{c}\text { TIDAK } \\
\text { MENJAWAB }\end{array}$ \\
\hline $\begin{array}{l}\text { 1) Saya mencuci tangan } \\
\text { sesampai di rumah }\end{array}$ & 32 & 5 & 0 & 5 \\
\hline $\begin{array}{l}\text { 2) Saya mencuci tangan } \\
\text { lebih dari } 20 \text { detik }\end{array}$ & 12 & 21 & 4 & 5 \\
\hline $\begin{array}{l}\text { 3) Saya mencuci tangan } \\
\text { dengan sabun }\end{array}$ & 36 & 1 & 1 & 4 \\
\hline $\begin{array}{l}\text { 4) Saya mencuci tangan } \\
\text { pada air yang } \\
\text { mengalir }\end{array}$ & 32 & 6 & 0 & 4 \\
\hline $\begin{array}{l}\text { 5) Saya selalu menjaga } \\
\text { jarak minimal 1-2 } \\
\text { meter dengan orang } \\
\text { lain }\end{array}$ & 13 & 23 & 2 & 4 \\
\hline $\begin{array}{l}\text { 6) Saya MEMBATASI } \\
\text { keluar rumah }\end{array}$ & 16 & 16 & 5 & 5 \\
\hline 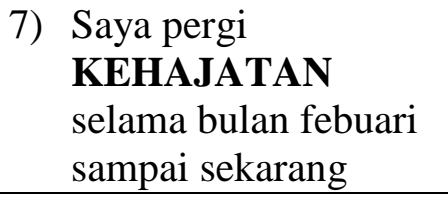 & 2 & 11 & 0 & 29 \\
\hline $\begin{array}{l}\text { 8) } \text { Saya pergi ke PASAR } \\
\text { TRADISIONAL } \\
\text { selama bulan febuari } \\
\text { sampai sekarang }\end{array}$ & 6 & 22 & 0 & 14 \\
\hline $\begin{array}{l}\text { 9) Saya pakai MASKER } \\
\text { KE LUAR RUMAH }\end{array}$ & 31 & 3 & 2 & 6 \\
\hline $\begin{array}{l}\text { 10) Saya MENYENTUH } \\
\text { WAJAH }\end{array}$ & 11 & 16 & 0 & 15 \\
\hline $\begin{array}{l}\text { 11) Saya pakai faceshield } \\
\text { (pelapis jernih depan } \\
\text { wajah) }\end{array}$ & 3 & 14 & 0 & 15 \\
\hline $\begin{array}{l}\text { 12) ANAK saya pakai } \\
\text { masker }\end{array}$ & 30 & 8 & 0 & 4 \\
\hline
\end{tabular}




\section{INTEGRITAS : Jurnal Pengabdian}

Vol 4, No 2, Desember 2020

ISSN 2580 - 7978 (cetak) ISSN 2615 - 0794 (online)

\section{DISKUSI}

Pengabdian ini dilakukan pada saat pandemi COVID-19 menginjak 5 bulan di Indonesia. Tingkat Pengetahuan yang dimiliki masyarakat Desa Sukamakmur dengan kategori kurang-sedang. Hal ini berbeda dengan survei yang diadakan di Denpasar, Bali, dengan responden $>50 \%$ dengan latar belakang pendidikan sarjana, tingkat pengetahuan pada masyarakat ini $70 \%$ baik. Hal ini menandakan latar belakang mempengaruhi tingkat pengetahuan masyarakat. Tingginya pengetahuan masyarakat akan membantu menekan penularan virus Corona tersebut.

Mengenai pembatasan aktivitas, pada survei kecil kali, kebanyakan masyakat belum mematuhi untuk pembatasan aktivitas. Survei ini dilakukan setelah 5 bulan masa pandemi, yang artinya, masyarakat sudah bosan dengan aktivitas rumah dan dengan kebutuhan ekonomi yang meningkat, aktivitas ke luar rumah sudah menjadi hal yang mesti ditempuh meskipun dengan risiko penularan yang tinggi. Pada survei melibatkan masyarakat pada 32 propinsi yang dilakukan pada tiga bulan pertama, 44,7 \% masyarakat mengurangi aktivitas, dan kurang lebih $6 \%$ masyarakat yang tetap beraktivitas seperti sebelum pandemi. Jika dilihat terjadi pergeseran sikap pada 5 bulan setelah pandemi.

Kebiasaan mencuci tangan pada masyarakat desa sukamakmur sudah baik. Perilaku Hidup Bersih dan Sehat (PHBS) adalah point penting dalam menekan penularan. Kebisaaan yang sudah baik di Desa Sukamakmur, tidak berlaku pada desa Guwosari, Kabupaten Bantul, Jawa Tengah. Hal ini menandakan tidak meratanya pengetahuan di masyarakat pedesaan antara Jawa Barat dan Jawa Tengah yang berjarak 300-500 km.

\section{KESIMPULAN}

Hasil pengabdian kepada masyarakat tentang penyuluhan covid setelah 5 bulan penyebaran COVID-19 di Indonesia memberikan petunjuk bahwa pengetahuan masyarakat masih rendah tentang covid dan kebiasaan masyarakat di desa Sukamakmur tentang perilaku pencegahan COVID-19 sudah cukup baik. 
INTEGRITAS : Jurnal Pengabdian

Vol 4, No 2, Desember 2020

ISSN $2580-7978$ (cetak) ISSN 2615 - 0794 (online)

\section{UCAPAN TERIMA KASIH}

1. LPPM Universitas Pembangunan Nasional Veteran Jakarta.

2. Dekan Fakultas Kedokteran Universitas Pembangunan Nasional Veteran Jakarta.

3. Komunitas Karate Indonesia.

\section{DAFTAR PUSTAKA}

Ambarwati ER, Prihastuti PJCAJPKM: Gerakan Masyarakat Hidup Sehat (Germas) Mencuci Tangan Menggunakan Sabun Dan Air Mengalir Sebagai Upaya Untuk Menerapkan Perilaku Hidup Bersih Dan Sehat (Phbs) Sejak Dini. 2019;1(1):45-52.

Data Sebaran 2020 [Available from: https://covid19.go.id/.

Novira N, Iskandar R, Bahraen RJJKI: Persepsi Masyarakat Akan Pentingnya Social Distancing Dalam Penanganan Wabah Covid-19 Di Indonesia. 2020:27-32.

Pradana M, Rubiyanti N, Hasbi I, Utami DGJLE: Indonesia's fight against COVID-19: the roles of local government units and community organisations. 2020;25(9):741-3.

Sukamakmur, Kabupaten Bogor 2020 [Available from: https://id.wikipedia.org/wiki/Sukamakmur,_Bogor.

Wulandari TS, Anisah RL, Fitriana NG, Purnamasari IJJIK: Pengaruh Pendidikan Kesehatan Dengan Media Leaflet Untuk Meningkatkan Pengetahuan dan Perilaku Dalam Upaya Menerapkan Protokol Kesehatan Pada Pedagang Di Car Free Day Temanggung. 2020;10(2):6-15. 